\title{
Nutritive evaluations of some browse tree foliages during the dry season: Secondary compounds, feed intake and in vivo digestibility in sheep and goats
}

\author{
A.Z.M. Salem ${ }^{\mathrm{a}, *}$, M.Z.M. Salem ${ }^{\text {b }}$, M.M. El-Adawy ${ }^{\mathrm{a}}$, \\ P.H. Robinson ${ }^{\mathrm{c}}$ \\ ${ }^{a}$ Department of Animal Production, Faculty of Agriculture (El-Shatby), \\ Alexandria University, Alexandria, Egypt \\ b Department of Timber Trees and Wood Technology, Faculty of Agriculture (El-Shatby), \\ Alexandria University, Alexandria, Egypt \\ ${ }^{c}$ Department of Animal Science, University of California, Davis, CA 95616-8521, USA
}

Received 26 April 2005; received in revised form 29 August 2005; accepted 8 September 2005

\begin{abstract}
Four browse tree foliages (Cassia fistula, Schinus molle, Chorisia speciosa and Eucalyptus camaldulensis), native to the semi-arid region of north Egypt, were harvested during the dry season and evaluated for nutritional quality by determination of levels of nutrient and secondary compounds, as well as feed intake and apparent digestibility in sheep and goats. The study consisted of four experiments conducted in sequential 28-day periods that were the same in all respects, except that a different foliage was evaluated in each experiment which used six adult male Rhmani sheep ( $35 \pm 2.3 \mathrm{~kg}$ body weight (BW) at the start of the study) and six crossbred goats $(30 \pm 1.56 \mathrm{~kg} \mathrm{BW})$. Sheep and goats were randomly divided into two groups of three and offered foliage at a level equal to 1.3 of the previous days voluntary intake of fresh matter and a commercial concentrate, with or without $10 \mathrm{~g} / \mathrm{animal} / \mathrm{d}$ of PEG, at $10 \mathrm{~g} / \mathrm{kg}$ of BW to meet 0.7 of maintenance metabolizable energy requirements. Foliage crude protein (CP) content ranged from 124 (S. molle) and 128 (C. speciosa) to $185 \mathrm{~g} / \mathrm{kg} \mathrm{DM}$ (C. fistula). Ether extract was highest $(97 \mathrm{~g} / \mathrm{kg})$ in S. molle. C. fistula had the lowest neutral detergent fiber
\end{abstract}

Abbreviations: BW, body weight; ADFom, acid detergent fiber; NDFom, neutral detergent fiber; Lignin(sa), acid detergent lignin; CP, crude protein; DM, dry matter; PEG, polyethylene glycol; TP, total phenolics; CT, condensed tannins; SAP, saponins; ALKA, alkaloids; AF, the aqueous fraction

* Corresponding author. Tel.: +20 3 5292727; fax: +20 35901900 .

E-mail address: asalem70@yahoo.com (A.Z.M. Salem). 
(NDFom), acid detergent fiber (ADFom) and acid detergent lignin (lignin(sa)), while E. camaldulensis had the highest values. Total phenolics (TP), condensed tannins (CT), saponins (SAP), alkaloids (ALKA), the aqueous fraction (AF) of lectins, polypeptides and starch, and essential oils (EO) were lowest in $C$. speciosa $(29,21,3,0,4 \mathrm{~g} / \mathrm{kg} \mathrm{DM}$ and $0.40 \mathrm{ml} / \mathrm{kg} \mathrm{DM}$, respectively) and highest in $E$. camaldulensis (102, 68, 15, 5, 3 g/kg DM and $15 \mathrm{ml} / \mathrm{kg}$ DM, respectively). Levels of TP, CT, SAP, ALKA and EO were highly positively intercorrelated among foliages, although AF was weakly negatively correlated to all others. Goats consumed 3.9\% more foliage dry matter (DM) than sheep per $\mathrm{kg} \mathrm{BW}^{0.75}$, and their digestibility was about $8 \%$ higher, probably reflecting their better capacity to detoxify secondary compounds in the rumen than sheep. Levels of CT (and due to its correlations, also TP, SAP, ALKA and EO) was a strong predictor of DM intake of PEG unsupplemented foliages within both sheep and goats. PEG increased $(\mathrm{P}<0.05)$ intake of $\mathrm{DM}$ and its components in sheep and goats. Digestion of DM and NDFom were not affected by feeding PEG, although digestion of OM, $\mathrm{EE}$ and $\mathrm{CP}$ were higher $(\mathrm{P}<0.05)$. TP in tree foliages (and due to its correlations, also CT, SAP, ALKA and EO) was not a predictor of the proportional increase in DM with PEG feeding, which was best predicted by level of CP within foliage. Overall, C. speciosa, had the highest nutrient value for both sheep and goats, both without and with PEG feeding, S. molle and C. fistula were intermediate and E. camaldulensis had the lowest nutritive value.

(C) 2005 Elsevier B.V. All rights reserved.

Keywords: Foliage; Secondary compounds; Feed intake; Digestibility; Sheep; Goats

\section{Introduction}

A major cause of low productivity of livestock in tropical regions, such as Egypt, is inadequate amounts, and poor nutritional quality, of many locally available feeds. Browse fodder is a potentially inexpensive locally produced protein supplement for ruminants, particularly during the critical periods of the year when the quantity and quality of herbage is limited. However, most tropical browse species contain substantial amounts of phenolic compounds, mainly tannins (Makkar and Becker, 1998; Salem, 2005) as well as other secondary compounds (Salem et al., 2004b). This can reduce their nutritional value, as most tannins bind to feed proteins thereby making them unavailable to ruminal microorganisms. Thus, the use of high tannin browse species as supplements to crop residue-based diets may not increase the productivity of animals, as ruminally available $\mathrm{N}$ frequently limits ruminal microbial growth and subsequent degradation of structural carbohydrates.

However, several fodder shrubs and trees have been shown to be able to partially or totally replace concentrate feeds without decreasing digestion or growth of sheep and goats. For example, Ondiek et al. (2000) concluded that Leucaena leucocephala and Gliricidia sepium foliage could contribute $\mathrm{N}$ in diet supplements without detrimental effects on production of dairy goats. Liu et al. (2001) showed that mulberry (Morus alba) leaves could be used as a protein supplement in an ammoniated rice straw diet to fully substitute for rapeseed meal.

Goats are effective browsers, have the ability to utilize woody species and low-quality forages better than cattle and sheep, and can adapt to harsh environments (Tisserand et al., 1991; Silanikove, 2000a, 2000b; Salem et al., 2004a). Extensive shrub-lands of evergreens 
and small trees, known as garrigue or maquis, that are often high in tannins and other secondary compounds are the basic component of diets of goats in the Mediterranean area.

Attempts have been made to deactivate tannins, and other secondary compounds, in temperate and tropical forages. These attempts include use of polyethylene glycol (PEG), a synthetic polymer for which tannins have a greater binding affinity than proteins (Makkar, 2003a). Therefore, PEG releases forage proteins from tannin-protein complexes and improves their nutritional value. Degen et al. $(1998,2000)$ used Acacia saligna, a tanninrich leguminous shrub species, and suggested that effects of PEG may persist for up to 14 days in sheep and goats after PEG feeding is terminated.

This study was designed to determine the nutritive value of four browse tree species in terms of nutrient and secondary compounds, and to assess the capability of PEG added to the diet to mitigate adverse effects of secondary compounds on feed intake and nutrient digestibility in sheep and goats.

\section{Materials and methods}

The study was completed at the experimental station of the Faculty of Agriculture of Alexandria University in northern Egypt during May-August 2004.

\subsection{Tree foliage species}

Consumable parts (i.e., leaves and twigs of about 1 year of age) of each foliage species used (i.e., Cassia fistula; Schinus molle; Chorisia speciosa; Eucalyptus camaldulensis) were randomly harvested, by hand plucking from 8 to 10 trees of each species, every second day.

\subsection{Animals, management and feeding}

This study consisted of four experiments completed in sequential 28 day periods that were the same in all respects, except that a different tree foliage was evaluated in each experiment which used six adult male Rahmani sheeps and six crossbred goats weighing $35 \pm 2.3$ and $30 \pm 1.56 \mathrm{~kg}$ body weight (BW), respectively, at the start of the study.

Sheep and goats were randomly divided into two groups of three to create the two experimental groups. All were offered foliage at a level equal to 1.3 of the previous days voluntary intake of fresh matter, and a commercial concentrate (with or without $10 \mathrm{~g}$ of PEG/animal/d; MW 4000, Analytical grade, Sigma ${ }^{\circledR}$-Aldrich, El-Safua Co., Alexandria, Egypt) at 10 g/kg of BW to meet 0.7 of their calculated maintenance metabolizable energy (ME) requirements (NRC, 1985). The concentrate used was formulated to contain undecorticated cotton seed meal $(300 \mathrm{~g} / \mathrm{kg})$, ground yellow corn $(355 \mathrm{~g} / \mathrm{kg})$, wheat bran $(300 \mathrm{~g} / \mathrm{kg})$, limestone $(30 \mathrm{~g} / \mathrm{kg})$, salt $(10 \mathrm{~g} / \mathrm{kg}$ ) and $5 \mathrm{~g} / \mathrm{kg}$ of a trace mineral/vitamin premix (all values/kg of DM: Vitamin A, 2,000,000 IU; Vitamin $\mathrm{D}_{3}, 150,000 \mathrm{IU}$; Vitamin K, $0.33 \mathrm{mg}$; Vitamin $\mathrm{B}_{1}, 0.33 \mathrm{~g}$; Vitamin $\mathrm{B}_{2}, 1.0 \mathrm{~g}$; Vitamin $\mathrm{B}_{6}, 0.33 \mathrm{~g}$; Vitamin $\mathrm{B}_{12}, 1.7 \mathrm{mg}$; pantathenic acid, $3.33 \mathrm{~g}$; biotin, $33.0 \mathrm{mg}$; Folic acid, $0.83 \mathrm{~g}$; choline chloride, $200 \mathrm{mg}$; Zn, $11.7 \mathrm{~g}$; Mn, $5.0 \mathrm{~g}$; Fe, $12.5 \mathrm{~g}$; Mg, $66.7 \mathrm{mg}$; 
Se, $16.6 \mathrm{mg}$; Co, $1.33 \mathrm{mg}$; Cu, $0.5 \mathrm{~g}$; I, $16.6 \mathrm{mg}$; antioxidant, $10.0 \mathrm{~g}$ ). The concentrate was fed at $9.00 \mathrm{~h}$ and animals were fed the foliage $10.00 \mathrm{~h}$ and allowed access to it until $2 \mathrm{~h}$ before the next feeding of concentrate, at which time uneaten foliage was removed and weighed. All offered concentrate was consumed by all sheep and goats within 60 min of offer on all occasions, and so orts were assumed to be foliage.

Sheep and goats were housed in individual pens during the adaptation period (i.e., the first 15 days of each experiment) to the dietary treatments and had free access to clean water.

\subsection{Metabolism trial (feed intake and apparent digestibility determinations)}

During each experiment, after the 15 day adaptation to dietary treatments, a digestion study of 10 days duration, involving quantitative collection of feeds, refusals and faeces was conducted to determine the apparent digestibility of the diets. Animals were acclimatized to the metabolism cages for 3 days after the 15 day adaptation period and prior to the 10 day collection period. Faeces voided during each successive $24 \mathrm{~h}$ period were collected and weighed. Representative samples of foliage, concentrate, refusals and faeces were collected daily and dried at $105^{\circ} \mathrm{C}$ to determine daily intake of DM for each animal. Other representative samples of each material, by animal for refusals and faeces, were collected daily over the 10 day collection period, bulked, mixed, sub-sampled and ground to pass a $1 \mathrm{~mm}$ sieve for subsequent laboratory analysis.

\subsection{Analytical methods}

Ground samples of feeds, refusals and faeces were analyzed for dry matter (DM) by drying samples at $105^{\circ} \mathrm{C}$ for $24 \mathrm{~h}$ in forced air oven. Ash content was measured after igniting samples in a muffle furnace at $550{ }^{\circ} \mathrm{C}$ for $4 \mathrm{~h}$. The crude protein $(\mathrm{CP})$ was determined by Kjeldahl method (AOAC, 1990; ID 954.01). Ether extract (EE) was determined by Soxhlet method (AOAC, 1990; ID 920.39). Neutral detergent fiber (NDFom), acid detergent fiber (ADFom) and acid detergent lignin (lignin(sa)) were determined by methods of Van Soest et al. (1991). NDFom was assayed without the use of an alpha amylase but with use of sodium sulfite. Both NDFom and ADFom are expressed without residual ash.

Samples of each tree foliage were dried at $40^{\circ} \mathrm{C}$ for $72 \mathrm{~h}$ and ground to pass a $1 \mathrm{~mm}$ sieve. All samples were thoroughly mixed and sub-sampled into four representative bulk samples of each foliage for further analysis of secondary compounds.

Approximately $200 \mathrm{mg}$ (DM) of ground samples of each foliage were extracted in $10 \mathrm{ml}$ of aqueous acetone $(7: 3 \mathrm{v} / \mathrm{v})$ in a water bath maintained at $39-40^{\circ} \mathrm{C}$ for $90 \mathrm{~min}$ (Makkar, 2000). Total extractable phenolics (TP) were assayed by Folin-Ciocalteu-reagent 2N (Sigma ${ }^{\circledR}$-Aldrich, El-Safua Co., Alexandria, Egypt) based on known concentrations of tannic acid as the calibration curve (Sigma ${ }^{\circledR}$-Aldrich) according to Makkar and Becker (1993). Condensed tannins (CT) were determined according to Porter et al. (1986) with the modification of Makkar $(2000,2003 \mathrm{~b})$ using butanol/ $\mathrm{HCl}(95: 5 \mathrm{v} / \mathrm{v})$ and ferric ammonium sulfate $(20 \mathrm{~g} / 12 \mathrm{M} \mathrm{HCl})$ as reagents, and a solution of purified quebracho tannin $(1 \mathrm{mg} / \mathrm{ml}$ aqueous acetone, $700 \mathrm{ml} / \mathrm{l}$ ) as the standard. Absorbance was measured against a blank at $550 \mathrm{~nm}$. 
Saponins (SAP) were extracted and isolated according to Ahmad et al. (1990), wherein dried samples are extracted with methanol several times. The combined methanol extract was evaporated and partitioned between ethanol acetate and $\mathrm{H}_{2} \mathrm{O}$. For the alkaloid (ALKA) extract, dried samples were first extracted with ethanol and then dissolved in dilute $\mathrm{HCl}$. This solution was filtered and extracted with petroleum ether to remove fat (Arambewela and Ranatunge, 1991).

The aqueous fraction (AF) of lectins, polypeptides and starch (see review of Cowan, 1999) was determined according to Hussein et al. (1999) using fractionation by column chromatography of extracted samples by saturating the extract with distilled $\mathrm{H}_{2} \mathrm{O}$ and $500 \mathrm{~g} / \mathrm{l}$ methanol. For essential oil (EO) analysis, fresh leaves of tree foliage were cut into small pieces $(0.2-0.4 \mathrm{~cm}$ length) with a small chopper and steam distilled. The distillate was then extracted with petroleum ether, and the resulting extract was dried on anhydrous sodium sulfate. Petroleum ether was removed carefully and EO was obtained as the liquid.

\subsection{Statistical analysis}

Tree foliage nutrient and secondary compound contents were statistically analyzed using the 'PROC GLM' procedure of SAS (1999), with methods of Steel and Torrie (1980), and differences among foliage species were determined using Duncan's multiple-range test (Duncan, 1955). Data on nutrient components of total feed intake, foliage consumed and digestibility were analyzed as $2 \times 2$ factorial experiments ( 2 animal species (sheep and goats) $\times 2$ treatments (with or without PEG)) within each tree foliage for each experiment using 'PROC GLM' (SAS, 1999), with methods of Steel and Torrie (1980), to determine differences due to animal species and PEG. In the case of significant interactions (i.e., $\mathrm{P}<0.05$ ), Duncan's multiple-range test (Duncan, 1955) was used to separate means within animal species. Correlations between foliage secondary compounds (Table 6) used simple linear regression (SAS, 1999), whereas multiple regressions (Table 7) used the 'PROC STEPWISE' procedure of SAS (1999).

\section{Results}

\subsection{Chemical composition and secondary compounds of the tree foliages}

The crude protein (CP) content of the foliages (Table 1) ranged from 124 (S. molle) and 128 (C. speciosa) to $185 \mathrm{~g} / \mathrm{kg} \mathrm{DM} \mathrm{(C.} \mathrm{fistula),} \mathrm{with} \mathrm{E.} \mathrm{camaldulensis} \mathrm{intermediate}$ $(154 \mathrm{~g} / \mathrm{kg})$. Ether extract was highest $(97 \mathrm{~g} / \mathrm{kg})$ in $S$. molle, with the others containing less than half that level. $C$. fistula had the lowest NDFom, ADFom and lignin(sa), E. camaldulensis had the highest values, and $S$. molle and $C$. speciosa were intermediate.

Total phenolics, condensed tannins, saponins, alkaloids, the aqueous fraction of lectins, polypeptides and starch, and essential oils were lowest in C. speciosa $(29,21,3,0,4 \mathrm{~g} / \mathrm{kg}$ $\mathrm{DM}$ and $0.40 \mathrm{ml} / \mathrm{kg} \mathrm{DM}$, respectively) and highest in E. camaldulensis $(102,68,15,5,3$ and 15). C. fistula and $S$. molle had intermediate values, although $S$. molle had higher levels of TP and CT. Tannins (i.e., TP and CT) were higher than $50 \mathrm{~g} / \mathrm{kg}$ of DM in S. molle (70 
Table 1

Nutrient and secondary compound levels $(\mathrm{g} / \mathrm{kg} \mathrm{DM})$ of foliages and the concentrate

\begin{tabular}{|c|c|c|c|c|c|c|}
\hline & \multicolumn{4}{|c|}{ Tree species } & \multirow[t]{2}{*}{ S.E.M. } & \multirow[t]{2}{*}{ Concentrate $^{a}$} \\
\hline & C. fistula & S. molle & C. speciosa & E. camaldulensis & & \\
\hline \multicolumn{7}{|c|}{ Chemical composition $^{b}$} \\
\hline $\mathrm{OM}$ & $923 b$ & $909 \mathrm{~d}$ & $916 \mathrm{c}$ & $945 \mathrm{a}$ & 0.88 & $965(0.6)$ \\
\hline $\mathrm{CP}$ & $185 \mathrm{a}$ & $124 \mathrm{~d}$ & $128 \mathrm{c}$ & $154 b$ & 0.95 & $147(2.3)$ \\
\hline $\mathrm{EE}$ & $39 c$ & $97 \mathrm{a}$ & $47 b$ & $41 \mathrm{bc}$ & 2.64 & $83(1.2)$ \\
\hline NDFom & $368 \mathrm{~d}$ & $515 b$ & $435 c$ & $615 \mathrm{a}$ & 4.47 & $289(3.4)$ \\
\hline ADFom & $200 \mathrm{~d}$ & $327 \mathrm{c}$ & $356 b$ & $542 \mathrm{a}$ & 5.56 & $186(2.1)$ \\
\hline Lignin(sa) & $101 \mathrm{c}$ & $160 b$ & $102 \mathrm{c}$ & $192 \mathrm{a}$ & 2.82 & $110(1.8)$ \\
\hline \multicolumn{7}{|c|}{ Secondary compounds ${ }^{c}$} \\
\hline $\mathrm{TP}$ & $44.3 \mathrm{c}$ & $67.7 \mathrm{~b}$ & $29.0 \mathrm{~d}$ & $102.3 \mathrm{a}$ & 2.76 & $12.4(1.6)$ \\
\hline $\mathrm{CT}$ & $31.6 \mathrm{c}$ & $49.2 \mathrm{~b}$ & $20.8 \mathrm{~d}$ & $68.1 \mathrm{a}$ & 0.96 & $\mathrm{ND}^{\mathrm{d}}$ \\
\hline SAP & $8.3 \mathrm{~b}$ & $10.3 \mathrm{~b}$ & $3.0 \mathrm{c}$ & $14.6 \mathrm{a}$ & 0.73 & ND \\
\hline ALKA & $1.3 \mathrm{~b}$ & $1.9 \mathrm{~b}$ & $0.0 \mathrm{c}$ & $5.0 \mathrm{a}$ & 0.20 & ND \\
\hline $\mathrm{AF}$ & $8.6 \mathrm{a}$ & $6.6 \mathrm{~b}$ & $3.9 \mathrm{c}$ & $2.4 \mathrm{~d}$ & 0.28 & ND \\
\hline EO & $0.8 \mathrm{c}$ & $5.3 \mathrm{~b}$ & $0.4 \mathrm{c}$ & $15.5 \mathrm{a}$ & 0.27 & ND \\
\hline
\end{tabular}

In the same row with different online letters $(\mathrm{a}, \mathrm{b}, \mathrm{c}, \mathrm{d})$ differ $(\mathrm{P}<0.05)$.

a Mean value \pm S.D.

b OM, organic matter; CP, crude protein; EE, ether extract; NDFom, neutral detergent fiber; ADFom, acid detergent fiber; lignin(sa), acid detergent lignin.

c TP, total extractable phenolic components; CT, condensed tannins (as quebracho equivalent); SAP, saponins; ALKA, alkaloids; AF, aqueous fraction (lectins, polypeptides, starch; Cowan, 1999); EO, essential oils (ml/kg DM).

d Assumed to be zero $(<0.01 \mathrm{~g} / \mathrm{kg} \mathrm{DM})$.

and 50) and E. camaldulensis (110 and 70), which is considered to be their upper beneficial level in ruminant nutrition (Mangan, 1988).

\subsection{Effects of tree foliage species on intake and digestion}

\subsubsection{C. fistula}

Water consumption was higher $(\mathrm{P}<0.05)$ in sheep, although the actual values are not convincing. Sheep also consumed more $(\mathrm{P}<0.01)$ total and foliage DM (absolutely and relative to $\mathrm{BW}$ ) than goats (Table 2), as well as all measured nutrients, although their digestion of nutrients, except NDFom, was lower $(\mathrm{P}<0.05)$.

Addition of PEG had no impact on water intake, but increased $(\mathrm{P}<0.05)$ intake of DM and its components in sheep and goats. Digestion of DM and NDFom were not affected by feeding PEG, although digestion of OM, EE and CP were higher $(\mathrm{P}<0.05)$.

\subsubsection{S. molle}

Water consumption was higher $(\mathrm{P}<0.05)$ in sheep, which consumed more $(\mathrm{P}<0.01)$ total, but not foliage, DM (absolute and relative to BW) than goats (Table 3), as well as all measured nutrients, although their digestion of nutrients, except NDFom, was lower $(\mathrm{P}<0.05)$.

Addition of PEG had no impact on water intake, but increased $(\mathrm{P}<0.05)$ intake of DM and its components absolutely, although relative to BW the increase in DM intake and digestibility was greater within goats $(\mathrm{P}=0.04)$. Digestion of $\mathrm{DM}$ and NDFom were not 
Table 2

Water intake $(1 / \mathrm{d})$, feed intake $(\mathrm{g} / \mathrm{d})$ and digestion $(\mathrm{g} / \mathrm{kg})$ in sheep and goats fed $C$. fistula in the absence $(-)$ or presence $(+)$ of PEG

\begin{tabular}{|c|c|c|c|c|c|c|c|c|}
\hline \multirow{2}{*}{$\begin{array}{l}\text { Species }(\mathrm{Sp}) \\
\text { PEG }\end{array}$} & \multicolumn{2}{|c|}{ Sheep } & \multicolumn{2}{|c|}{ Goats } & \multirow[t]{2}{*}{ S.E.M. } & \multicolumn{3}{|c|}{ Significance $(\mathrm{P})$} \\
\hline & - & + & - & + & & $\mathrm{Sp}$ & PEG & $\mathrm{Sp} \times \mathrm{PEG}$ \\
\hline Water intake (1/d) & 2.3 & 3.0 & 2.5 & 2.5 & 0.08 & 0.01 & 0.40 & 0.65 \\
\hline \multicolumn{9}{|c|}{ Dry matter (DM) intake } \\
\hline Foliage (g/d) & 309 & 329 & 262 & 272 & 4.2 & $<0.01$ & 0.03 & 0.41 \\
\hline Foliage $\left(\mathrm{g} / \mathrm{kg}^{0.75}\right)$ & 21.4 & 22.9 & 20.4 & 21.2 & 0.31 & 0.02 & 0.03 & 0.48 \\
\hline Concentrate $^{\mathrm{a}}$ & 320 & 320 & 274 & 274 & & & & \\
\hline Total (g/d) & 629 & 649 & 536 & 546 & 4.2 & $<0.01$ & 0.03 & 0.41 \\
\hline Total $\left(\mathrm{g} / \mathrm{kg}^{0.75}\right)$ & 43.8 & 45.2 & 41.9 & 42.6 & 0.31 & $<0.01$ & 0.03 & 0.48 \\
\hline DM digestion & 502 & 525 & 549 & 565 & 4.6 & 0.01 & 0.25 & 0.06 \\
\hline \multicolumn{9}{|l|}{ Organic matter } \\
\hline Intake & 594 & 613 & 507 & 516 & 3.9 & $<0.01$ & 0.03 & 0.41 \\
\hline Digestion & 531 & 547 & 579 & 595 & 4.0 & $<0.01$ & 0.02 & 0.98 \\
\hline \multicolumn{9}{|l|}{ Ether extract } \\
\hline Intake & 26 & 27 & 22 & 23 & 0.2 & $<0.01$ & 0.03 & 0.41 \\
\hline Digestion & 527 & 556 & 556 & 570 & 6.1 & 0.04 & 0.04 & 0.41 \\
\hline \multicolumn{9}{|l|}{ Crude protein } \\
\hline Intake & 104 & 108 & 89 & 91 & 0.8 & $<0.01$ & 0.03 & 0.41 \\
\hline Digestion & 521 & 536 & 565 & 606 & 7.2 & $<0.01$ & 0.02 & 0.23 \\
\hline \multicolumn{9}{|l|}{ Neutral detergent fiber } \\
\hline Intake & $206 b$ & $214 \mathrm{a}$ & $132 \mathrm{~b}$ & $179 a$ & 1.4 & $<0.01$ & $<0.01$ & $<0.01$ \\
\hline Digestion & 448 & 468 & 464 & 482 & 7.3 & 0.20 & 0.10 & 0.92 \\
\hline
\end{tabular}

In the same row (within animal species) with different letters $(a, b)$ differ $(\mathrm{P}<0.05)$.

${ }^{a}$ Concentrate intake was not statistically analyzed as it was offered at a flat rate.

affected by feeding PEG, although digestion of $\mathrm{OM}, \mathrm{EE}$ and $\mathrm{CP}$ were higher $(\mathrm{P}<0.05)$ with PEG feeding.

\subsubsection{C. speciosa}

Water consumption was higher $(\mathrm{P}=0.02)$ in sheep, which consumed more $(\mathrm{P}<0.01)$ total and foliage $\mathrm{DM}$ than goats absolutely (but less $(\mathrm{P}<0.01)$ foliage than goats relative to $\mathrm{BW})$ (Table 4), as well as all measured nutrients, although their digestion of nutrients, except $\mathrm{CP}$ and NDFom, was lower $(\mathrm{P}<0.05$ except $\mathrm{OM} \mathrm{P}=0.06)$.

Addition of PEG had no impact on water intake, but increased $(\mathrm{P}<0.05)$ intake of $\mathrm{DM}$ and its components both absolutely and relative to $\mathrm{BW}$, although relative to $\mathrm{BW}$ the increase in total DM intake was greater within goats $(\mathrm{P}=0.01)$. Digestion of $\mathrm{CP}$ and NDFom were not affected by feeding $\mathrm{PEG}$, although digestion of $\mathrm{DM}, \mathrm{OM}$ and $\mathrm{EE}$ were higher $(\mathrm{P}<0.05)$ with PEG feeding.

\subsubsection{E. camaldulensis}

Water consumption was unaffected by animal species, but sheep consumed more $(\mathrm{P}<0.01)$ total, but not foliage, DM than goats absolutely (although goats consumed more 
Table 3

Water intake $(1 / \mathrm{d})$, feed intake $(\mathrm{g} / \mathrm{d})$ and digestion $(\mathrm{g} / \mathrm{kg})$ in sheep and goats fed $S$. molle in the absence $(-)$ or presence $(+)$ of PEG

\begin{tabular}{|c|c|c|c|c|c|c|c|c|}
\hline & \multicolumn{2}{|l|}{ Sheep } & \multicolumn{2}{|l|}{ Goats } & \multirow[t]{2}{*}{ S.E.M. } & \multicolumn{3}{|c|}{ Significance $(\mathrm{P})$} \\
\hline & - & + & - & + & & $\mathrm{Sp}$ & PEG & $\mathrm{Sp} \times \mathrm{PEG}$ \\
\hline Water intake $(1 / d)$ & 3.6 & 3.1 & 2.9 & 2.8 & 0.1 & 0.04 & 0.25 & 0.90 \\
\hline \multicolumn{9}{|c|}{ Dry matter (DM) intake } \\
\hline Foliage $(\mathrm{g} / \mathrm{d})$ & 269 & 316 & 259 & 331 & 4.9 & 0.75 & $<0.01$ & 0.11 \\
\hline Foliage $\left(\mathrm{g} / \mathrm{kg}^{0.75}\right)$ & $18.7 \mathrm{~b}$ & $22.0 \mathrm{a}$ & $20.2 \mathrm{~b}$ & $25.8 \mathrm{a}$ & 0.35 & $<0.01$ & $<0.01$ & 0.04 \\
\hline Concentrate $^{\mathrm{a}}$ & 320 & 320 & 274 & 274 & & & & \\
\hline Total (g/d) & 589 & 636 & 533 & 605 & 4.9 & 0.02 & 0.01 & 0.11 \\
\hline Total $\left(\mathrm{g} / \mathrm{kg}^{0.75}\right)$ & $41.0 \mathrm{~b}$ & $44.3 \mathrm{a}$ & $41.6 \mathrm{~b}$ & $47.2 \mathrm{a}$ & 0.35 & 0.01 & $<0.01$ & 0.04 \\
\hline DM digestion & 505 & 506 & 529 & 544 & 4.3 & $<0.01$ & 0.19 & 0.13 \\
\hline \multicolumn{9}{|l|}{ Organic matter } \\
\hline Intake & 554 & 596 & 500 & 566 & 4.5 & $<0.01$ & $<0.01$ & 0.11 \\
\hline Digestion & 538 & 544 & $567 \mathrm{~b}$ & $605 a$ & 6.2 & $<0.01$ & 0.02 & 0.04 \\
\hline \multicolumn{9}{|l|}{ Ether extract } \\
\hline Intake & 40 & 44 & 37 & 44 & 0.5 & 0.03 & $<0.01$ & 0.11 \\
\hline Digestion & 511 & 536 & 544 & 559 & 5.8 & 0.01 & 0.04 & 0.54 \\
\hline \multicolumn{9}{|l|}{ Crude protein } \\
\hline Intake & 80 & 86 & 72 & 81 & 0.6 & $<0.01$ & $<0.01$ & 0.11 \\
\hline Digestion & 496 & 528 & 544 & 608 & 6.2 & $<0.01$ & $<0.01$ & 0.10 \\
\hline \multicolumn{9}{|c|}{ Neutral detergent fiber } \\
\hline Intake & $231 \mathrm{~b}$ & $225 \mathrm{a}$ & $164 \mathrm{~b}$ & $250 \mathrm{a}$ & 2.5 & $<0.01$ & $<0.01$ & $<0.01$ \\
\hline Digestion & 491 & 503 & 496 & 522 & 7.5 & 0.29 & 0.11 & 0.52 \\
\hline
\end{tabular}

In the same row (within animal species) with different letters $(a, b)$ differ $(\mathrm{P}<0.05)$.

${ }^{a}$ Concentrate intake was not statistically analyzed as it was offered at a flat rate.

( $\mathrm{P}=0.01$ ) foliage DM relative to BW) (Table 5), as well as all measured nutrients, although their digestion of nutrients was lower $(\mathrm{P}<0.05$ except $\mathrm{EE} \mathrm{P}=0.06)$.

Addition of $\mathrm{PEG}$ tended $(\mathrm{P}=0.06)$ to increase water consumption, although the actual values are not convincing. Addition of PEG only increased $(\mathrm{P}<0.05)$ intake of NDFom, although intake of DM and all other measured components tended $(\mathrm{P}<0.10)$ to be higher. Digestion of EE and NDFom were not affected by PEG, although digestion of DM, OM and $\mathrm{CP}$ were higher $(\mathrm{P}<0.05$ except $\mathrm{DM} \mathrm{P}=0.07)$ with $\mathrm{PEG}$.

\section{Discussion}

\subsection{Composition of the tree foliages}

High CP, and low NDFom and ADFom levels, suggest browse with potential as $\mathrm{N}$ supplements to ruminants fed low quality forages during the dry season in semi-arid regions. Use of multipurpose trees and shrubs has become a useful alternative ruminant feed in harsh semi-arid environments (FAO, 1992; Topps, 1992). Differences in CP con- 
Table 4

Water intake (1/d), feed intake $(\mathrm{g} / \mathrm{d})$ and digestion $(\mathrm{g} / \mathrm{kg})$ in sheep and goats fed $C$. speciosa in the absence $(-)$ or presence $(+)$ of PEG

\begin{tabular}{|c|c|c|c|c|c|c|c|c|}
\hline & \multicolumn{2}{|l|}{ Sheep } & \multicolumn{2}{|l|}{ Goats } & \multirow[t]{2}{*}{ S.E.M. } & \multicolumn{3}{|c|}{ Significance $(\mathrm{P})$} \\
\hline & - & + & - & + & & $\mathrm{Sp}$ & PEG & $\mathrm{Sp} \times \mathrm{PEG}$ \\
\hline Water intake (1/d) & 2.6 & 2.8 & 2.3 & 2.3 & 0.09 & 0.02 & 0.77 & 0.59 \\
\hline \multicolumn{9}{|c|}{ Dry matter (DM) intake } \\
\hline Foliage (g/d) & 439 & 484 & 400 & 468 & 5.9 & 0.01 & $<0.01$ & 0.20 \\
\hline Foliage $\left(\mathrm{g} / \mathrm{kg}^{0.75}\right)$ & 30.5 & 33.6 & 31.3 & 36.6 & 0.45 & 0.02 & $<0.01$ & 0.12 \\
\hline Concentrate $^{\mathrm{a}}$ & 320 & 320 & 274 & 274 & & & & \\
\hline Total (g/d) & 760 & 804 & 675 & 743 & 5.9 & $<0.01$ & $<0.01$ & 0.20 \\
\hline Total $\left(\mathrm{g} / \mathrm{kg}^{0.75}\right)$ & $52.9 \mathrm{~b}$ & $56.0 \mathrm{a}$ & $52.7 \mathrm{~b}$ & $58.0 \mathrm{a}$ & 0.44 & 0.21 & $<0.01$ & 0.01 \\
\hline DM digestion & 524 & 556 & 609 & 624 & 5.9 & $<0.01$ & 0.02 & 0.30 \\
\hline \multicolumn{9}{|l|}{ Organic matter } \\
\hline Intake & 711 & 752 & 631 & 694 & 5.4 & $<0.01$ & $<0.01$ & 0.20 \\
\hline Digestion & 552 & 578 & 573 & 596 & 6.3 & 0.06 & 0.03 & 0.89 \\
\hline \multicolumn{9}{|l|}{ Ether extract } \\
\hline Intake & 35 & 37 & 31 & 34 & 0.3 & $<0.01$ & $<0.01$ & 0.20 \\
\hline Digestion & 503 & 515 & 515 & 548 & 4.5 & 0.01 & 0.01 & 0.12 \\
\hline \multicolumn{9}{|l|}{ Crude protein } \\
\hline Intake & 103 & 109 & 92 & 100 & 0.8 & $<0.01$ & $<0.01$ & 0.20 \\
\hline Digestion & 516 & 536 & 538 & 544 & 6.5 & 0.14 & 0.19 & 0.46 \\
\hline \multicolumn{9}{|l|}{ Neutral detergent fiber } \\
\hline Intake & $284 b$ & $303 a$ & $222 b$ & $283 \mathrm{a}$ & 2.5 & $<0.01$ & $<0.01$ & $<0.01$ \\
\hline Digestion & 509 & 519 & 516 & 523 & 6.5 & 0.57 & 0.35 & 0.88 \\
\hline
\end{tabular}

In the same row (within animal species) with different letters $(\mathrm{a}, \mathrm{b})$ differ $(\mathrm{P}<0.05)$.

a Concentrate intake was not statistically analyzed as it was offered at a flat rate.

tents between these browses are probably due to differences in protein accumulation in them during growth. The reported nutrient levels are comparable to those found by Le Houérou (1980), Topps (1992) and Rubanza et al. (2003), although some inconsistencies (e.g., Rubanza et al. reported values ranging from 115 to 205,52 to 126,182 to 619,68 to 196 and 44 to $130 \mathrm{~g} / \mathrm{kg} \mathrm{DM}$ for CP, ash, NDFom, ADFom, and lignin(sa), respectively, in browse legume tree leaves native to Tanzania) are likely due to differences in the stage of growth and type (i.e., twigs, leaves or soft stem) of foliage sampled. Inconsistencies could also be due to sampling site and climatic influences on foliage growth and plant nutrient accumulation.

High secondary compound contents in foliages are mainly a property of plant genotypic factors controlling physiological synthesis and accumulation of secondary compounds (Okuda et al., 1993; Kelman et al., 1997). Other factors associated with high rates of polyphenolic synthesis include high environmental temperatures, drought stress, and plant defensive mechanisms against pests, pathogens and predators (Mangan, 1988). Shayo and Uden (1999) and Abdulrazak et al. (2000) also reported high phenolic and tannin levels in some East African browses. High polyphenolic components were also reported in semi-arid of north Egypt (Salem, 2005) and arid regions of Sudan (Fadel Elseed et al., 2002). 
Table 5

Water intake $(1 / \mathrm{d})$, feed intake $(\mathrm{g} / \mathrm{d})$ and digestion $(\mathrm{g} / \mathrm{kg})$ in sheep and goats fed E. camaldulensis in the absence $(-)$ or presence $(+)$ of PEG

\begin{tabular}{|c|c|c|c|c|c|c|c|c|}
\hline & \multicolumn{2}{|c|}{ Sheep } & \multicolumn{2}{|c|}{ Goats } & \multirow[t]{2}{*}{ S.E.M. } & \multicolumn{3}{|c|}{ Significance $(\mathrm{P})$} \\
\hline & - & + & - & + & & $\mathrm{Sp}$ & PEG & $\mathrm{Sp} \times \mathrm{PEG}$ \\
\hline Water intake (1/d) & 2.3 & 3.1 & 3.4 & 2.9 & 0.13 & 0.67 & 0.06 & 0.37 \\
\hline \multicolumn{9}{|c|}{ Dry matter (DM) intake } \\
\hline Foliage (g/d) & 222 & 239 & 233 & 244 & 5.2 & 0.29 & 0.09 & 0.70 \\
\hline Foliage $\left(\mathrm{g} / \mathrm{kg}^{0.75}\right)$ & 15.4 & 16.6 & 18.2 & 19.1 & 0.37 & 0.01 & 0.09 & 0.78 \\
\hline Concentrate $^{\mathrm{a}}$ & 320 & 320 & 274 & 274 & & & & \\
\hline Total (g/d) & 542 & 559 & 508 & 519 & 5.2 & 0.01 & 0.09 & 0.70 \\
\hline Total $\left(\mathrm{g} / \mathrm{kg}^{0.75}\right)$ & 37.8 & 39.0 & 36.6 & 40.5 & 0.38 & 0.01 & 0.09 & 0.78 \\
\hline DM digestion & 506 & 506 & 518 & 560 & 6.9 & 0.01 & 0.07 & 0.07 \\
\hline \multicolumn{9}{|l|}{ Organic matter } \\
\hline Intake & 519 & 535 & 485 & 496 & 4.9 & $<0.01$ & 0.09 & 0.71 \\
\hline Digestion & 513 & 531 & 557 & 588 & 6.5 & $<0.01$ & 0.03 & 0.47 \\
\hline \multicolumn{9}{|l|}{ Ether extract } \\
\hline Intake & 23 & 24 & 21 & 22 & 0.2 & $<0.01$ & 0.09 & 0.70 \\
\hline Digestion & 503 & 526 & 533 & 555 & 9.6 & 0.06 & 0.15 & 0.92 \\
\hline \multicolumn{9}{|l|}{ Crude protein } \\
\hline Intake & 81 & 84 & 76 & 78 & 0.8 & 0.01 & 0.09 & 0.70 \\
\hline Digestion & $492 b$ & $520 \mathrm{a}$ & $505 \mathrm{~b}$ & $600 a$ & 7.0 & $<0.01$ & $<0.01$ & 0.01 \\
\hline \multicolumn{9}{|l|}{ Neutral detergent fiber } \\
\hline Intake & 229 & 240 & 205 & 230 & 3.2 & 0.01 & 0.01 & 0.17 \\
\hline Digestion & 431 & 437 & 453 & 456 & 5.7 & 0.04 & 0.62 & 0.92 \\
\hline
\end{tabular}

Means in the same row (within animal species) with different letters $(\mathrm{a}, \mathrm{b})$ differ $(\mathrm{P}<0.05)$.

${ }^{a}$ Concentrate intake was not statistically analyzed as it was offered at a flat rate.

There were differences between levels of TP and CT in the tree foliages studied compared to similar tree foliages reported by others (e.g., Rubanza et al. (2003) reported TP and CT were between 65-237 and 6-74 g/kg DM, respectively). This may, at least partly, be due to different assays and assay standards, although variability in chemical composition of polyphenolics among foliages (Makkar and Becker, 1993; Pino et al., 2005) may also be a factor. Some differences might also have been due to stage of plant growth and/or season of collection (Salem, 2005), site of sampling (Makkar and Becker, 1998), and/or proportions of foliage materials sampled (Salem, 2005).

In the current study, the secondary compounds SAP, ALKA, AF and EO were determined for the first time in these tree foliage species. However, their interpretive value relative to prediction of negative impacts of plant secondary compound levels on voluntary DM intake and animal performance may be modest, particularly for SAP, ALKA and EO, which were very strongly positively correlated to TP and CT in these tree foliages (Table 6). In contrast, AF was weakly negatively correlated to TP and CT, as well as SAP, ALKA and EO, suggesting that it may have value in predicting voluntary DM intake and performance of animals fed tree foliages. 
Table 6

Intercorrelations $(r)$ of plant secondary compounds ${ }^{\mathrm{a}}$

\begin{tabular}{lrrrrr}
\hline & \multicolumn{1}{c}{ TP } & CT & SAP & ALKA & AF \\
\hline CT & 0.997 & & & & \\
SAP & 0.963 & 0.968 & & & \\
ALKA & 0.980 & 0.964 & 0.952 & & \\
AF & -0.458 & -0.413 & -0.212 & -0.475 & -0.646 \\
EO & 0.971 & 0.953 & 0.883 & 0.973 & \\
\hline
\end{tabular}

a TP, total phenolics; CT, condensed tannins; SAP, saponins; Alka, alkaloids; AF, aqueous fraction.

\subsection{Effect of animal species}

Inter-animal species differences in voluntary intake of these foliages, without addition of PEG, were inconsistent among the foliages. While sheep ate more grams per day of $C$. fistula, S. Molle and C. speciosa than goats, intake of E. camaldulensis was slightly higher in goats. In contrast, sheep ate more $C$. fistula than goats relative to $\mathrm{BW}$, but goats ate more of the other three foliages. Over all PEG unsupplemented foliages, goats consumed 3.9\% more foliage DM than sheep per $\mathrm{kg}$ of $\mathrm{BW}^{0.75}$ (Fig. 1), a finding consistent with Gilboa et al. (1995) who found that goats were able to consume larger amounts of tannin-rich browse than sheep under similar conditions, probably due, at least partially, to the ability of goats to detoxify higher amounts of tannins or secondary compounds versus other ruminants (Silanikove et al., 1996). In addition, goats, as browsers, may have selected the parts of the foliage with a higher proportion of $\mathrm{CP}$, and lower proportion of fiber and/or secondary compounds, versus sheep as grazers (Kababya et al., 1998; Salem, 2002; Salem et al., 2003). However, this is speculatory, as the composition of the uneaten feed was not determined.

Salem et al. (2004a) observed an increase in the number of eating bouts of short duration in goats fed alfalfa hay treated with $50 \mathrm{~g}$ quebracho/kg DM, versus sheep fed the same hay, and suggested that this may be a mechanism used by goats to minimize negative effects of secondary compounds in foliages. The mobile upper lip of goats allows them to browse

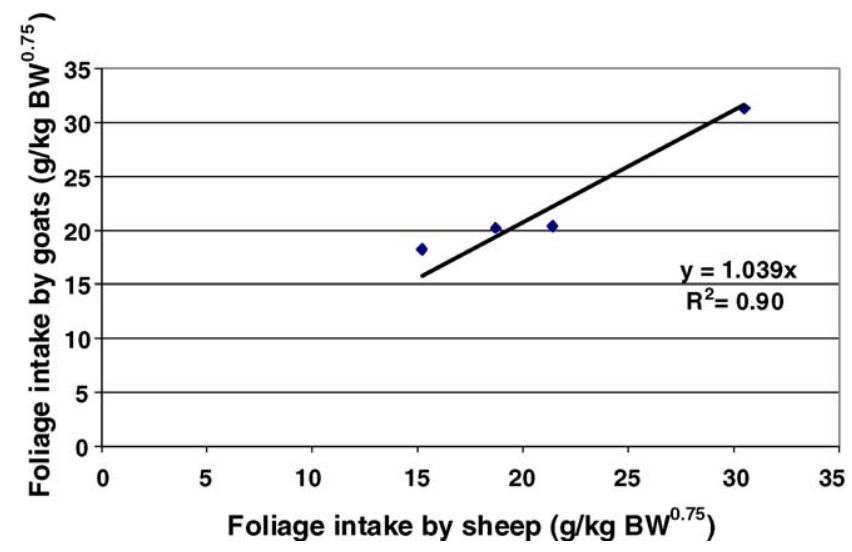

Fig. 1. Relationship between PEG unsupplemented foliage intake by goats and sheep (the intercept was 0 ). 
a variety of plants to obtain nutrients under harsh conditions. In many studies (Tisserand et al., 1991; Silanikove, 2000a, 2000b; Salem et al., 2004a), goats had the ability to utilize woody species and low quality forages better than cattle and sheep, and were able to adapt better to harsh environments, such as the extensive shrub lands of evergreen shrubs and small trees, that are the basic component of the diets of goats raised in the Mediterranean basin.

In spite of the higher PEG unsupplemented foliage DM intake relative to BW of goats versus sheep in three of the four foliages, an event that would be expected to suppress digestibility (NRC, 2001), digestion of DM, and its measured components (except NDFom which was only numerically higher in three of the four foliages) were consistently higher in goats. For example, average DM digestibility was $509 \mathrm{~g} / \mathrm{kg}$ in sheep and $551 \mathrm{~g} / \mathrm{kg}$ in goats unsupplemented with PEG, suggesting an approximate increase of $8 \%$ in the energetic value of these foliages to goats versus sheep. In addition to the advantages of goats versus sheep noted above, their ability to consume larger amounts of tannin-rich browse (Gilboa et al., 1995) and ability detoxify higher amounts of tannins (or other secondary compounds) versus other ruminants (Silanikove et al., 1996), may occur by development of adaptive mechanisms in response to the presence of secondary compounds in the diet (Provenza and Malechek, 1984; Silanikove et al., 1996; Kababya et al., 1998; Salem et al., 2004a). Such an adaptive mechanism may be due to the existence of ruminal bacteria, such as Streptococcus caprins, in goats that has the ability to degrade tannin-protein complexes (Brooker et al., 1994). In addition, goats, as browsers, may have selected the parts of the foliage with a lower proportion of secondary compounds, versus sheep as grazers (Kababya et al., 1998; Salem, 2002; Salem et al., 2003).

\subsection{Effect of PEG supply}

Polyethylene glycol is widely used to neutralize tannins and other secondary compounds in foliages. Formation of complexes between PEG and secondary compounds, particularly tannins, from leaves of trees and shrubs was investigated by Makkar et al. (1995a), and the affinity of tannins for PEG at various pH's was demonstrated. Positive effects of PEG feeding on feed intake, digestibility, rumen fermentation, microbial synthesis, daily gain and wool growth by sheep and goats fed tannin rich forages have been widely demonstrated (Pritchard et al., 1992; Miller et al., 1997; Silanikove et al., 1997; Degen et al., 1998; Ben Salem et al., 2000; Decandia et al., 2000; Barry et al., 2001), but the nature and magnitude of the positive impact is thought to depend on factors such as tannin structure, level of tannin in the foliage, PEG dose level and means of administration, animal species and diet composition.

In the current study, the level of CT (as well as the levels of TP, SAP and ALKA due to their high correlations to CT levels as shown in Table 6) was a strong predictor of foliage DM intake (g/d), explaining 0.81 and 0.60 of the variation (i.e., $\left.r^{2}\right)$ in sheep and goat DM intake, respectively (Table 7). Levels of $\mathrm{AF}$ and $\mathrm{CP}$ in the foliages were poor predictors ( $r^{2}$ from $<0.01$ to 0.20 ) of DM intake, but when CP was added to CT, 0.87 and 0.78 of the variation in sheep and goat DM intake, respectively, was explained and if AF was added to CT, predictions were essentially perfect. Clearly four foliage observations are insufficient to support firm conclusions, but it suggests that negative effects of CT on DM intake can 
Table 7

Power $\left(r^{2}\right)$ of CT, AF and CP to predict foliage DM intake $(\mathrm{g} / \mathrm{d})$ by sheep and goats fed foliages not supplemented with PEG, and to predict the percentage increase in foliage DM intake due to feeding PEG

\begin{tabular}{|c|c|c|c|c|}
\hline \multirow[t]{2}{*}{ Predictor $^{\mathrm{a}}$} & \multicolumn{2}{|c|}{ DM intake } & \multicolumn{2}{|c|}{ DM intake increase $(\%)$} \\
\hline & Sheep & Goats & Sheep & Goats \\
\hline $\mathrm{CT}$ & 0.81 & 0.60 & $<0.01$ & 0.04 \\
\hline $\mathrm{AF}$ & $<0.01$ & 0.04 & 0.01 & $<0.01$ \\
\hline $\mathrm{CP}$ & 0.08 & 0.20 & 0.62 & 0.64 \\
\hline $\mathrm{CT}+\mathrm{CP}$ & 0.87 & 0.78 & 0.62 & 0.76 \\
\hline $\mathrm{AF}+\mathrm{CP}$ & 0.10 & 0.20 & 0.87 & 0.99 \\
\hline $\mathrm{CT}+\mathrm{AF}$ & 0.99 & 0.99 & 0.02 & 0.04 \\
\hline
\end{tabular}

${ }^{\text {a }} \mathrm{CT}$, condensed tannins; $\mathrm{AF}$, aqueous fraction; $\mathrm{CP}$, crude protein.

be counteracted to only a slight degree by lower levels of $\mathrm{CP}$, but to a substantive extent by higher levels of AF.

In general, these results are consistent with findings of others. For example, secondary compounds, particularly phenolics, could act by lowering foliage palatability by their negative effects in the mouth, such as by astringent bitterness (Jackson et al., 1996), binding to salivary proteins in the mouth (Wong, 1973; Salem et al., 2000), or by negative effects on gustative receptors (McLeod, 1974). Higher levels of secondary compounds in foliages, particularly in E. camaldulensis, during eating could have negatively affected salivation rate, which could have increased the astringent taste and so decreased feed intake (Salem et al., 2000, 2001). Reduced salivation might also have negatively affected ruminal microbial activity (Salem et al., 2002) and inhibited enzyme production (Dawson et al., 1999; Barry and McNabb, 1999; Salem et al., 2002). In addition, secondary compounds perturb intestinal wall permeability through reactions with intestinal membrane proteins (McLeod, 1974; Zimmer and Cordesse, 1996; Fondevila et al., 2002).

Studies on tannin-saponin interactions which suggested that effects of both tannins and saponins to decrease in vitro digestibilities and gas production were additive (Makkar et al., 1995b; Makkar, 2003a), do not support the hypothesis that simultaneous presence of tannins and saponins might alleviate the adverse effect of each other. For example, Johnson et al. (1986) found that some saponins increase the permeability of intestinal mucosal cells in vitro, inhibit active mucosal transport and facilitate intestinal absorption of compounds that are normally not absorbed.

The EO, which are the volatile components responsible for some of the characteristic aroma of foliage species, may also have negative effects on DM intake. EO appear to have selective antibacterial activity (Janssen et al., 1986; Demetzos et al., 1997; Newbold et al., 2004), and Nagy and Tengerdy (1968) found that addition of EO extracted from Sagebush (Atemisa tridentate) altered the rumen bacterial population composition.

Feeding PEG has been shown to improve intake of foliage containing secondary compounds in goats (Silanikove et al., 1997; Decandia et al., 2000) and sheep (Silanikove et al., 1994; Salawu et al., 1997). It has also been shown to increase availability of nutrients in the gastrointestinal tract and so increase digestibility (Ben Salem et al., 2005). However, the actual chemical linkages between tannins and PEG that neutralize the negative effects of secondary compounds of foliages to allow increased feed intake and digestibility are not 
clear. Consistent with results of others, supplementation of PEG to sheep and goats in the current study increased foliage DM intake and digestion to variable extents in both animal species fed all foliages.

The foliages used in the current study had very different levels of secondary compounds (e.g., the CT of E. camaldulensis was 3.27 times that of C. speciosa), and it might have been expected that PEG feeding would have a larger positive impact on DM intake in foliages with higher level of secondary compounds. However, this was not the case. The level of CT (as well as the levels of TP, SAP and ALKA due to their high correlations to CT levels as shown in Table 6) was not a predictor of the percentage increase in foliage DM intake due to feeding PEG in either sheep or goats, explaining only $<0.01$ and 0.04 of the variation for sheep and goats, respectively, increase in foliage DM intake due to PEG (Table 7). The best single (negative) predictor of the percentage increase in foliage DM intake due to PEG feeding was the CP level of the foliage, explaining 0.62 and 0.64 of the variation for sheep and goats, respectively. If CT was added to $\mathrm{CP}$ as a predictor, the variation explained did not change (i.e., 0.62 and 0.76), however addition of $\mathrm{AF}$ (positive) to $\mathrm{CP}$ increased the variation explained to 0.87 and 0.99 , respectively, for sheep and goats.

The inability of CT (and by correlation the other secondary compounds) to explain the percentage increase in DM due to PEG feeding contrasts to the ability of CT to predict the absolute DM intake of these foliages. However, as previously noted, four foliage observations are insufficient for firm conclusions, although it does suggest that the positive effects of PEG on DM intake may not be related to its levels of CT, or other secondary compounds, but due to associations with $\mathrm{CP}$ and AF that overcome the negative affects of secondary compounds on DM intake and digestion.

\section{Conclusions}

The nutritional quality of the browse tree foliages C. fistula, S. molle, C. speciosa and E. camaldulensis, native to the semi-arid region of north Egypt, were evaluated by determining levels of nutrients and secondary compounds, as well as feed intake and apparent digestibility in sheep and goats. Goats consumed 3.9\% more DM than sheep per kg BW ${ }^{0.75}$, and their digestibility was about $8 \%$ higher. Levels of CT (and due to its correlations, also TP, SAP, ALKA and EO) was a strong predictor of DM intake of PEG unsupplemented foliages in both sheep and goats. PEG increased intake of DM and its components in both sheep and goats, but levels of TP (and due to its correlations, also CT, SAP, ALKA and EO) was not a predictor of the proportional increase in DM with PEG feeding, which was best predicted by the level of CP within foliage (negative), which was improved by adding AF (positive) to the prediction. C. speciosa, had the highest nutrient value for both sheep and goats, both without and with PEG feeding, S. molle and $C$. fistula were intermediate and $E$. camaldulensis had the lowest nutritive value.

\section{References}

Abdulrazak, S.A., Fujihara, T., Ondiek, J.K., Ørskov, E.R., 2000. Nutritive evaluation of some Acacia tree leaves from Kenya. Anim. Feed Sci. Technol. 85, 89-98. 
Ahmad, V.U., Perveen, S., Bano, S., 1990. Saponins from the leaves of Guaiacum officinale. Phytochemistry 29, 3287-3290.

AOAC, 1990. Official Methods for Analysis, 15th ed. Association of Official Analytical Chemists, Arlington, VA.

Arambewela, L.S.R., Ranatunge, T., 1991. Indole alkaloids from Tabernaemontana divaricata. Phytochemistry 30, 1740-1741.

Barry, T.N., McNabb, W.C., 1999. The implication of condensed tannins on the nutritive value of temperature forage fed to ruminants. Br. J. Nutr. 81, 263-272.

Barry, T.N., McNeill, D.M., McNabb, W.C., 2001. Plant secondary compounds; their impact on forage nutritive value and upon animal production. In: Proceedings of the XIX International Grassland Congress, pp. 445-452.

Ben Salem, H., Ben Salem, I., Ben Said, M.S., 2005. Effect of the level and frequency of PEG supply on intake, digestion, biochemical and clinical parameters by goats given kermes oak (Quercus coccifera L.)-based diets. Small Rumin. Res. 56, 127-137.

Ben Salem, H., Nefzaoui, A., Ben Salem, L., Tisserand, J.L., 2000. Deactivation of condensed tannins in Acacia cyanophylla Lindl. foliage by polyethylene glycol in feed blocks: Effects on feed intake, diet digestibility, nitrogen balance, microbial synthesis and growth by sheep. Livest. Prod. Sci. 64, 51-60.

Brooker, J.D., OǐDonovan, L.A., Skene, I., Clarke, K., Blackall, L., Muslera, P., 1994. Streptococcus caprinus sp. nov., a tannin-resistant ruminal bacterium from feral goats. Lett. Appl. Microbiol. 18, 313-318.

Cowan, M.M., 1999. Plant Products as Antimicrobial Agents. Clin. Microbiol. Rev. 12, 564-582.

Dawson, J.M., Buttery, P.J., Jenkins, D., Wood, C.D., Gill, M., 1999. Effects of dietary quebracho tannin on nutrient utilization and tissue metabolism in sheep and rats. J. Sci. Food Agric. 79, 1423-1430.

Decandia, M., Sitzia, M., Cabiddu, A., Kababya, D., Molle, G., 2000. The use of polyethylene glycol to reduce the antinutritional effects of tannins in goats fed woody species. Small Rumin. Res. 38, 157-164.

Degen, A.A., Benjamin, R.W., Mishorr, T., Kam, M., Becker, K., Makkar, H.P.S., Schwartz, H.J., 2000. Acacia saligna as a supplementary feed for grazing desert sheep and goats. J. Agric. Sci. (Camb.) 135, 77-84.

Degen, A.A., Mishorr, T., Makkar, H.P.S., Kam, M., Benjamin, R.W., Becker, K., Schwartz, H.J., 1998. Effect of Acacia saligna with and without administration of polyethylene glycol on dietary intake in desert sheep. Anim. Sci. 67, 491-498.

Demetzos, C., Katerinopoulos, H., Kouvarakis, A., Stratigakis, N., Loukis, A., Ekonomakis, C., Spiliotis, V., Tsaknis, J., 1997. Composition, antimicrobial activity of essential oil of Cistus creticus subsp. eriocephalus. Plant. Med. 63, 477-479.

Duncan, D.B., 1955. Multiple ranges and multiple $F$-test. Biometrics 11, 1-42.

Fadel Elseed, A.M.A., Anim, A.E., Khadiga, Abdel Ati, A., Sekine, J., Hishinuma, M.K., Hamana, K., 2002. Nutritive evaluation of some fodder tree species during dry season in central Sudan. Asian-Aust. J. Anim. Sci. 1, 844-850.

Fondevila, M., Nogueira-Filho, J.C.M., Barrios-Urdaneta, A., 2002. In vitro microbial fermentation and protein utilization of tropical forage legumes grown during the dry season. Anim. Feed Sci. Technol. 95, 1-14.

Food Agriculture Organization (FAO), 1992. Legume trees and other fodder trees as protein sources for livestock. In: Speedy, A., Pugliese, P.L. (Eds.), Proceedingsd of the FAO Expert Consultation. Malaysian Agricultural Research and Development Institute (MARDI) Kuala Lumpur, Malaysia, October 14-18, 1991, p. 339.

Gilboa, N., Nir, I., Nitsan, Z., Silanikove, N., Perevolotsky, A., 1995. Effect of polyethylene glycol on feed intake, body weight and digestibility in goats fed tannin-rich leaves. Hassadeh 75, 72-73.

Hussein, G., Nakamura, N., Meselhy, M.R., Hattori, M., 1999. Phenolics from Maytenus senegalensis. Phytochemistry 50, 689-694.

Jackson, F.S., McNabb, W.C., Barry, T.N., Foo, Y.L., Peters, J.S., 1996. The condensed tannin content of a range of subtropical and temperature forages and the reactivity of condensed tannin with ribulose-1,5-bis-phosphate carboxylase (Rubisco) protein. J. Sci. Food Agric. 72, 483-492.

Janssen, A.M., Chin, N.L., Scheffer, J.J.M., Baerheim-Svendsen, A., 1986. Screening for antimicrobial activity of some essential oils by the agar overlay technique. Pharm. Weekblad-Sci. Ed. 8, 289-292.

Johnson, I.T., Gee, J.M., Price, K., Curl, C., Fenwick, G.R., 1986. Influence of saponins on gut permeability and active nutrient transport in vitro. J. Nutr. 116, 2270-2277.

Kababya, D., Perevolotsky, A., Bruckental, I., Landau, S., 1998. Selection of diets by dual-purpose member goats in Mediterranean woodland. J. Agric. Sci. 131, 221-228. 
Kelman, W.M., Blumenthal, M.J., Harris, C.A., 1997. Genetic variation for seasonal herbage yield, growth habit, and condensed tannins in Lotus pedunculatus Cav. and Lotus corniculatus. Aust. J. Agric. Res. 48, 959-968.

Le Houérou, H.N., 1980. Fourrages ligneux en Afrique du Nord. In: Le Houérou, H.N. (Ed.), Les fourrages ligneux en Afrique. Etat actuel des connaissances. Colloque sur les fourrages ligneux en Afrique, Addis Abeba, Ethiopia, pp. 57-84.

Liu, J.X., Jun, Y., Yan, B., Yu, J.Q., Shi, Z.Q., 2001. Effects of mulberry leaves to replace rapeseed meal on performance of sheep feeding on ammoniated rice straw diet. Small Rumin. Res. 39, 131-136.

Makkar, H.P.S., 2000. Quantification of Tannins in Tree Foliage. A Laboratory Manual for the FAO/IAEA Coordinated Research Project on the Use of Nuclear and Related Techniques to Develop Simple Tannin Assays for Predicting and Improving the Safety and Efficiency of Feeding Ruminants on Tanniniferous Tree Foliage. FAO/IAEA Working Document, IAEA, Vienna, Austria, p. 38.

Makkar, H.P.S., 2003a. Effects and fate of tannins in ruminant animals, adaptation to tannins, and strategies to overcome detrimental effects of feeding tannin-rich feeds. Small Rumin. Res. 49, 241-256.

Makkar, H.P.S., 2003b. Quantification of tannins in tree and shrub foliage. In: Makkar, H.P.S. (Ed.), A Laboratory Manual. Kluwer Academic Publishers/FAO/IAEA, Vienna, Austria, p. 102.

Makkar, H.P.S., Becker, K., 1993. Behaviour of tannic acid from various commercial sources towards some chemical and protein precipitation assays. J. Sci. Food Agric. 62, 295-299.

Makkar, H.P.S., Becker, K., 1998. Do tannins in leaves of trees and shrubs from African and Himalayan regions differ in the level and activity? Agroforest. Syst. 40, 59-68.

Makkar, H.P.S., Blümmel, M., Becker, K., 1995a. Formation of complexes between polyvinyl pyrrolidones or polyethylene glycols and tannins, and their implication in gas production and true digestibility in in vitro techniques. Br. J. Nutr. 73, 897-913.

Makkar, H.P.S., Blümmel, M., Becker, K., 1995b. In vitro effects and interactions between tannins and saponins and fate of tannins in the rumen. J. Sci. Food Agric. 69, 481-493.

Mangan, J.L., 1988. Nutritional effects of tannins in animal feed. Nutr. Res. Rev. 1, 209-231.

McLeod, M.N., 1974. Plants Tannins: Their role in forage quality. Nutr. Abst. Rev. 44, 3-815.

Miller, S.M., Pritchard, D.A., Eady, S.J., Martin, P.R., 1997. Polyethylene glycol is more effective than surfactants to enhance digestion and production in sheep fed mulga (Acacia aneura) under pen and paddock conditions. Aust. J. Agric. Res. 48, 1121-1127.

Nagy, J.G., Tengerdy, R.P., 1968. Antibacterial action of essential oils of Artemisia as an ecological factor II antibacterial action of the volatile oils of Artemisia tridentata (Big Sagebrush) on bacteria from the rumen of mule deer. Appl. Microbiol. 16, 441-444.

Newbold, C.J., McIntosh, F.M., Williams, P., Riccardo Losa, Wallace, R.J., 2004. Effects of a specific blend of essential oil compounds on rumen fermentation. Anim. Feed Sci. Technol. 114, 105-112.

NRC, 1985. Nutrient Requirements of Domestic Animals. National Research Council, Washington, DC, USA.

NRC, 2001. Nutrient Requirements of Domestic Animals, 7th Rev. Ed. National Research Council, Washington, DC, USA.

Pino, M.A., Hervas, G., Mantecon, A., Giraldez, F.J., Frutos, P., 2005. Comparison of biological and chemical methods, and internal and external standards, for assaying tannins in Spanish shrub species. J. Sci. Food Agric. 85, 583-590.

Okuda, T., Yoshida, T., Hatano, T., 1993. Classification of oligomeric hydrolysable tannins and specificity of their occurrence in plants. Phytochemistry 32, 507-521.

Ondiek, J.O., Tuitoek, J.K., Abdulrazak, S.A., Bareeba, F.B., Fujihara, T., 2000. Use of Leucaena leucocephala and Gliricidia sepium as nitrogen sources in supplementary concentrates for dairy goats offered rhodes grass hay. Asian-Aust. J. Anim. Sci. 13, 1249-1254.

Porter, L.J., Hrstich, L.N., Chan, B.G., 1986. The conversion of proanthocyanidins and prodelphinidins to cyanidin and delphinidin. Phytochemistry 25, 223-230.

Pritchard, D.A., Martin, P.R., O'Rourke, P.K., 1992. The role of condensed tannins in the nutritional value of mulga (Acacia aneura) for sheep. Aust. J. Agric. Res. 43, 1739-1746.

Provenza, F.D., Malechek, J.C., 1984. Diet selection by domestic goats in relation to blockbrush twig chemistry. J. Appl. Ecol. 21, 831-841.

Rubanza, C.D.K., Shem, M.N., Otsyina, R., Ichinohe, T., Fujihara, T., 2003. Nutritive evaluation of some browse tree legume foliages native to semi-arid area in western Tanzania. Asian-Aust. J. Anim. Sci. 16, 1429-1437. 
Salawu, M.B., Acamovic, T., Stewart, C.S., Hovel, B., De, F.D., 1997. Quebracho tannins with or without Browse Plus (a commercial preparation of polyethylene glycol) in sheep diets: Effect on digestibility of nutrients in vivo and degradation of grass hay in sacco and in vitro. Anim. Feed Sci. Technol. 69, 67-78.

Salem, A.Z.M., 2002. Parotid saliva production and composition, feeding behavior, rumen fermentation, digestibility, and plasmatic parameters in sheep and goats: evolution of the response to the condensed tannins of quebracho in the diet. PhD Thesis. University of Leon, Leon, Spain.

Salem, A.Z.M., 2005. Impact of season of harvest on in vitro gas production and dry matter degradability of Acacia saligna leaves with inoculum from three ruminant species. Anim. Feed Sci. Technol. 123-124P1, 67-69.

Salem, A.Z.M., Gohar, Y.M., El-Adawy, M.M., Salem, M.Z.M., 2004b. Growth-inhibitory effect of some antinutritional factors extracted from Acacia saligna leaves on intestinal bacteria activity in sheep. Proceedings of the 12th Scientific Conference of the Egyptian Society of Animal Production (ESAP). Egypt. Soc. Anim. Prod. 41, 283-300.

Salem, A.Z.M., González, J.S., López, S., Ranilla, M.J., 2000. The effect of feeding alfalfa treated with quebracho on parotid salivation in sheep. In: Van Arendonk, J.A.M. (Ed.), Proceedings of the 51st Annual Meeting of the European Association for Animal Production (EAAP), Session N5.17. Wageningen Press, The Hague, The Netherlands, p. 152.

Salem, A.Z.M., González, J.S., López, S., Ranilla, M.J., 2001. Evolución de la respuesta en la producción unilateral de saliva parotidea a la inclusión de quebracho en la dieta en ganado ovino y caprino. En: Asociación Interprofesional para el Desarrollo Agrario (AIDA) IX Jornadas sobre producción Animal, Tomo I, pp. 322-324.

Salem, A.Z.M., González, J.S., López, S., Ranilla, M.J., Andrés, S., 2003. Efecto del tratamiento de heno de alfalfa con quebracho sobre su digestibilidad en el ganado caprino. En: Asociación Interprofesional para el Desarrollo Agrario (AIDA) X Jornadas sobre producción Animal, Tomo II, pp. 684-686.

Salem, A.Z.M., Gonzalez, J.S., Lopez, S., Ranilla, M.J., 2004a. Feeding behaviour patterns and water intake in sheep and goats fed alfalfa hay treated with quebracho. OPTIONS Méditerranéennes 59, 215-219.

SAS, 1999. SAS/STAT User's Guide, Version 6, 4th ed. SAS Institute, Cary, NC, USA.

Shayo, C.M., Uden, P., 1999. Nutritional uniformity of neutral detergent solubles in some tropical browse leaf and pod diets. Anim. Feed Sci. Technol. 82, 63-73.

Silanikove, N., 2000a. Interrelationship between water, food and digestible energy intake in desert and temperate goats. Appetite 12, 163-170.

Silanikove, N., 2000b. The physiological basis of adaptation in goats to harsh environments. Small Rumin. Res. $35,181-193$.

Silanikove, N., Gilboa, N., Nitsan, Z., 1997. Interactions among tannins, supplementation and polyethylene glycol in goats given oak leaves: effect on digestion and food intake. Anim. Sci. 64, 479-483.

Silanikove, N., Gilboa, N., Nir, I., Perevolotsky, A., Nitsan, Z., 1996. Effect of a daily supplementation of polyethylene glycol on intake and digestion of tannin-containing leaves (Quercus calliprinos, Pisticia lentiscus and Ceratonia siliqua) by goats. J. Agric. Food Chem. 44, 199-205.

Silanikove, N., Nitsan, Z., Perevolotsky, A., 1994. Effect of daily supplementation of polyethylene glycol on intake and digestion of tannin-containing leaves (Ceratonia siliquq) by sheep. J. Agric. Food Chem. 42, 2844-2847.

Steel, R.G.D., Torrie, J.H., 1980. Principles and Procedures of Statistics, 2nd ed. McGraw-Hill International, New York, NY, USA.

Tisserand, J.L., Hadjipanayiotou, M., Gihad, E.A., 1991. Digestion in goats. In: Morand-Fehr (Ed.), Goat Nutrition. Pudoc, Wageningen, The Netherlands, pp. 46-60.

Topps, J.H., 1992. Potential, composition and use of legume shrubs and trees as fodder for livestock in the tropics. J. Agric. Sci. Camb. 118, 1-8.

Van Soest, P.J., Robertson, J.B., Lewis, B.A., 1991. Methods for dietary fibre, neutral detergent fibre, and non-starch carbohydrates in relation to animal nutrition. J. Dairy Sci. 74, 3583-3597.

Wong, E., 1973. Plant phenolics. In: Butler, G.W., Bailey, R.W. (Eds.), Chemistry and Biochemistry of Herbage. Academic Press, London, UK, pp. 265-322.

Zimmer, N., Cordesse, R., 1996. Influence des tanins sur la valeur nutritive des aliments des ruminants. Prod. Anim. 9, 167-179. 